\title{
HUAQIAO DAN HUAREN: SEBUAH TINJAUAN HISTORIS
}

\author{
Joanessa M. J. S. Seda
}

\begin{abstract}
Abstrak
Tulisan ini membahas tentang sejarah kemunculan dan perkembangan dua istilah dalam bahasa Tionghoa yang populer digunakan untuk mengidentifikasi orang-orang Tionghoa yang bermigrasi ke luar Tiongkok yaitu Huaqiao dan Huaren. Ternyata ada dua faktor penting yang mempengaruhi proses kemunculan dan perkembangan dua istilah ini yaitu faktor migrasi orang-orang Tionghoa ke luar Tiongkok serta faktor perkembangan politik di dalam maupun di luar Tiongkok. Tanpa adanya faktor migrasi, maka istilah Huaqiao dan Huaren ini tentu tidak akan eksis. Kalau pun eksis, kemunculan dan perkembangan makna yang melekat pada kedua istilah ini sangat dipengaruhi oleh persepsi dari pihak-pihak yang terlibat dan berkepentingan dalam proses migrasi tersebut. Munculnya persepsi ini tak dapat dilepaskan dari faktor politik di dalam maupun di luar Tiongkok. Faktor-faktor inilah yang membawa istilah Huaqiao dan Huaren sampai pada makna yang mereka capai saat ini.
\end{abstract}

\section{Kata Kunci}

Huaqiao, Huaren, Qiao, Qiaoyu, Qiaoju, migrasi, kekaisaran Tiongkok, wilayah "Laut Selatan", orang Tionghoa di luar Tiongkok.

\begin{abstract}
This paper talks about the history of the birth and development of the terms Huaqiao and Huaren, the popular terms in Chinese for Chinese people who migrated out of China. In fact, there were two important factors which influenced the birth and development process of these terms. Those were the migration of the Chinese people out of China and the political development in and outside China. Without migration, these terms would not exist. Even if they exist, the birth and development of their meaning were influenced by the perceptions of all people who were involved and had interest in this migration process. These perceptions would not exist without the influence of the political condition and situation in and outside China. It is these factors which bring the terms Huaqiao and Huaren to its present meaning.
\end{abstract}

\section{Keywords}

Huaqiao, Huaren, Qiao, Qiaoyu, Qiaoju, migration, Chinese empire, "Southern Sea" region, Chinese people outside China.

\section{PENDAHULUAN}

Identitas merupakan unsur yang sangat signifikan bagi setiap individu karena berkenaan dengan jati diri seseorang. Namun menurut Wang Gungwu, orang Tionghoa tidak pernah mempunyai konsep identitas melainkan hanya memiliki 'konsep ke- 
Tionghoa-an, menjadi Tionghoa dan menjadi bukan Tionghoa' (seperti yang dikutip dalam buku Ma \& Cartier, 2003:54). Apa yang dikemukakan Wang ini merupakan suatu masalah laten bagi orang-orang Tionghoa yang migrasi ke luar Tiongkok, baik dalam menghadapi pemerintah dan masyarakat setempat maupun pemerintah Tiongkok. Bagaimana orang Tionghoa di luar Tiongkok mendefinisikan ke-Tionghoa-an mereka, siapa saja yang dianggap sebagai orang Tionghoa dan bukan Tionghoa, merupakan inti permasalahan dari tulisan ini. Namun faktor-faktor ini tidak dapat hanya dilihat dari satu sudut pandang saja. Meski pun apa yang dibahas dalam tulisan ini akan lebih banyak menyoroti masalah itu dari sudut pandang pemerintah Tiongkok, tetapi ada bagian di mana sudut pandang orang Tionghoa di luar Tiongkok itu sendiri juga akan menjadi fokus bahasan.

Cara terbaik untuk dapat memahami konsep ke-Tionghoa-an yang ada di benak orang Tionghoa ini maupun pemerintah Tiongkok ialah dengan memerhatikan istilah yang mereka gunakan untuk menyebut diri mereka. Sebutan ini sangatlah variatif karena terdiri dari sejumlah istilah yang berbeda. Tiap-tiap istilah mengandung konotasi yang berbeda karena proses kemunculan dan perkembangannya dipengaruhi oleh berbagai macam faktor. Dua faktor yang akan diulas dalam tulisan ini ialah faktor persepsi pemerintah Tiongkok mengenai migrasi orang-orang Tionghoa ke luar Tiongkok serta faktor perkembangan situasi dan kondisi politik internal Tiongkok maupun eksternalnya yang berbeda pula. Kedua faktor inilah yang menyebabkan istilah untuk menyebut orang-orang Tionghoa di luar Tiongkok, sejak kemunculannya hingga kini, terus mengalami perubahan dan perdebatan, terutama di Asia Tenggara. Namun bukan liku-liku perdebatannya yang akan dikemukakan dalam tulisan ini, melainkan bagaimana pasang-surut perubahan istilah untuk menyebut orang-orang Tionghoa di luar Tiongkok itu terjadi. Untuk itu, ada sejumlah pertanyaan yang bisa diajukan sehubungan dengan masalah istilah ini. Istilah mana yang akan dibahas dalam tulisan ini? Apa arti harafiah dari kata yang membentuk istilah tersebut? Kapan istilah itu muncul? Apa yang melatarbelakangi munculnya istilah itu? Bagaimana proses munculnya istilah itu? Apa konotasi yang terkandung di dalamnya? Bagaimana proses perkembangan dan perubahan dari penggunaan istilah itu? Apakah terjadi perubahan makna? Pertanyaan-pertanyaan inilah yang akan coba dijawab dalam tulisan ini.

\section{ISTILAH HUAQIAO}

\section{A. ASAL-USUL}

Istilah ini merupakan istilah dalam bahasa Mandarin yang digunakan untuk menyebut orang-orang Tionghoa yang migrasi ke luar dari daerah asalnya, dalam pengertiannya sebagai orang-orang "Tionghoa perantauan". Apa yang dimaksud dengan "Tionghoa perantauan" ialah orang-orang Tionghoa yang tinggal sementara di luar daerah asalnya dengan maksud akan kembali ke daerah asalnya pada suatu saat 
(Kuhn, 2008:15). Istilah Huaqiao (华侨) ini terdiri dari dua kata yaitu Hua (华) dan qiao ( 侨). Kata Hua berarti Zhongguo (中国) yang artinya "Negara Tengah" yang mengacu pada Tiongkok. Kata qiao artinya perjalanan atau tinggal sementara dan dalam kaitannya dengan migrasi orang-orang Tionghoa ke luar dari daerah asalnya, kata ini seringkali dipadukan dengan dua istilah lainnya yaitu qiaoju dan qiaoyu. Qiaoju (侨居) artinya penduduk sementara yang dikaitkan dengan pengertian "musafir" (Wang, 1992:2) sedangkan qiaoyu (侨寓) artinya tinggal sementara (Wang, 1992:6).

Pada mulanya, istilah qiaoju dan qiaoyu ini digunakan oleh kekaisaran Tiongkok untuk menyebut secara resmi pemukiman orang-orang Tionghoa di Tiongkok bagian utara yang terpaksa pindah ke selatan karena diusir oleh orang-orang Turki dan karena invasi etnis lain. Kemudian pada abad 18, keduanya digunakan untuk menyebut secara resmi pemukiman orang-orang Tionghoa dari propinsi Fujian dan Guangdong yang terpaksa migrasi ke Taiwan pada masa itu di bawah pimpinan Zheng Zhilong dan anaknya Zheng Chenggong (郑成功, Koxinga) yang dianggap sebagai pemberontak oleh kekaisaran Tiongkok. Dari kedua contoh di atas ini dapat disimpulkan bahwa istilah qiaoju dan qiaoyu mengandung beberapa pengertian. Pertama, bahwa migrasi orang Tionghoa ke luar dari daerah asalnya bersifat terpaksa dan hanya sementara saja. Terkandungnya unsur keterpaksaan dalam pengertian ini bisa dikaitkan dengan konsep migrasi tradisonal Tionghoa yang menyatakan bahwa tidak ada satu orang Tionghoa yang menghargai jati dirinya mau pergi meninggalkan daerah asalnya untuk selamanya tetapi hanya akan berkelana sebagai seorang "perantau" (Ma \& Cartier, 2003:52). Di samping itu, munculnya pengertian ini juga dikarenakan adanya konsep keluarga tradisional Tionghoa (jia,家) yang artinya kurang lebih "rumah-tangga pemilik tanah". Salah satu prinsip dasar dalam konsep ini ialah bahwa bagian yang menjadi hak dari anggota keluarga tidak akan hilang bersama waktu atau pun jarak (Kuhn, 2008:15). Dengan demikian berarti bahwa jika tidak karena alasan yang sangat mendesak, maka tidak ada orang Tionghoa yang mau pergi meninggalkan daerah asalnya. Sekali pun pergi dari daerah asalnya, ia pasti akan kembali karena tetap mempunyai hak atas hak milik keluarga yang menjadi bagiannya. Kedua, istilah qiaoju dan qiaoyu juga mengandung pengertian bahwa migrasi orang Tionghoa ke luar dari daerah asalnya mendapat semacam persetujuan dari pemerintah maupun rakyat kekaisaran Tiongkok, dalam arti baik rakyat maupun pemerintah Tiongkok menyadari bahwa perpindahan orang-orang Tionghoa ke luar dari daerah asalnya akan menyebabkan terbentuknya pemukiman orang-orang Tionghoa di daerah di mana mereka menetap untuk sementara waktu (Wang, 1992:3). Jadi pada awalnya, istilah Huaqiao ini mengacu pada orang-orang Tionghoa yang pindah dari daerah asalnya ke daerah lain dalam wilayah kekaisaran Tiongkok karena terdesak oleh keadaan, yang kemudian membentuk pemukiman di daerah yang mereka tuju dan pada suatu saat, akan kembali ke daerah asal mereka. 


\section{B. PERKEMBANGAN}

Seiring dengan berkembangnya waktu, istilah Huaqiao (dalam kaitannya dengan istilah qiaoju dan qiaoyu) mengalami beberapa tahap perkembangan. Perkembangan ini diawali dengan kepergian orang-orang Tionghoa ke wilayah "Laut Selatan" (Nanyang; 南 洋) yaitu wilayah di kawasan laut Cina Selatan yang mencakup wilayah pantai dataran Asia Tenggara serta sebagian besar dari kepulauan Filipina dan Indonesia, yang dicapai oleh orang-orang Tionghoa melalui jalur pelayaran (Wang, 1992:11). Mula-mula, antara abad 5-8 M, mereka mengunjungi wilayah "Laut Selatan" dalam perjalanan menuju India sebagai peziarah agama Budha. Berdasarkan data sejarah yang ada, diketahui bahwa pada abad $11 \mathrm{M}$, barulah orang-orang Tionghoa datang ke wilayah "Laut Selatan" ini sebagai pedagang dalam jumlah yang cukup signifikan. Para pedagang ini harus pinjam modal untuk dapat membiayai pelayaran mereka dan seringkali setibanya di tempat tujuan, mereka tinggal di sana selama sepuluh tahun lebih sebelum kembali ke Tiongkok untuk melunasi utang mereka. Hingga kini, belum ada data sejarah yang menunjukkan terbentuknya pemukiman orang-orang Tionghoa di wilayah "Laut Selatan" sebagai dampak dari pelayaran ini namun sekurang-kurangnya, hal ini menunjukkan bahwa sudah terbentuk hubungan dagang yang mapan antara Tiongkok dengan wilayah "Laut Selatan". Hubungan dagang ini kian berkembang antara abad 10-13 M, setelah kekaisaran Tiongkok di bawah pemerintahan dinasti Song (宋朝) dan Yuan (元朝) melakukan pengembangan armada laut dan memberi pinjaman modal kepada para pedagang Tionghoa untuk melakukan hubungan dagang dengan wilayah "Laut Selatan". Sebagian besar keuntungan dari hasil hubungan dagang tersebut menjadi pemasukan bagi kekaisaran Tiongkok. Di akhir abad $13 \mathrm{M}$, hubungan dagang ini berkembang pesat dan berdasarkan catatan seorang saksi mata yaitu seorang pejabat dinasti Yuan yang berkunjung ke Kamboja pada masa itu, ditemukan dua hal baru. Pertama, bahwa di salah satu bagian dari wilayah "Laut Selatan" sudah ada pemukiman orang-orang Tionghoa. Kedua, bahwa banyak pedagang Tionghoa yang menikahi perempuan lokal. Pada paruh pertama abad $14 \mathrm{M}$, berdasarkan catatan pribadi seorang musafir Tionghoa yaitu Wang Dayuan, diketahui adanya keterlibatan para pedagang Tionghoa secara aktif dalam kegiatan perdagangan di sejumlah daerah di wilayah Laut Selatan. Jika dikaitkan dengan pengertian kata qiao di atas, maka paparan di atas ini menghasilkan sejumlah kesimpulan. Pertama, bahwa telah terjadi migrasi orang-orang Tionghoa, bukan hanya antar daerah di Tiongkok, tetapi bahkan ke luar dari Tiongkok. Kedua, adanya dukungan modal dari pemerintah kekaisaran Tiongkok menunjukkan bahwa baik pemerintah maupun rakyat Tiongkok menyadari akan adanya kemungkinan terbentuknya pemukiman orang-orang Tionghoa di luar Tiongkok. Ketiga, bahwa memang telah terbentuk pemukiman orang-orang Tionghoa di luar Tiongkok, sekali pun kekaisaran Tiongkok tidak mau mengakuinya. Keempat, adanya hubungan timbalbalik antara berkembangnya hubungan dagang antara Tiongkok dengan wilayah "Laut 
Selatan" dengan terjadinya migrasi orang-orang Tionghoa ke luar Tiongkok. Hanya ada dua faktor yang tidak terlihat dalam paparan di atas ini. Pertama, bahwa kepergian orang-orang Tionghoa ke luar Tiongkok dilakukan karena terdesak atau karena adanya unsur keterpaksaan. Kedua, bahwa semua orang Tionghoa yang pergi ke luar Tiongkok tersebut pasti hanya akan tinggal sementara saja di daerah yang menjadi tujuan mereka. Karena kecuali data sejarah yang menunjukkan adanya pedagang-pedagang Tionghoa yang datang ke wilayah "Laut Selatan" dan tinggal sementara di wilayah tersebut pada abad $11 \mathrm{M}$, tidak diketahui adanya data sejarah lain yang mendukung pendapat bahwa para migran Tionghoa itu pasti akan kembali ke Tiongkok.

Jatuhnya dinasti Yuan pada paruh kedua abad $14 \mathrm{M}$ membawa perubahan baru dalam hubungan dagang antara Tiongkok dengan wilayah “Laut Selatan”. Dinasti Ming (明朝, 1368-1644) yang menggantikan dinasti Yuan menganggap bahwa hubungan dagang ini membahayakan kepentingan dan keamanan wilayah kekaisaran Tiongkok, apalagi setelah terjadinya pemberontakan-pemberontakan di sepanjang pesisir pantai selatan Tiongkok sejak abad 16 M. Maka pemerintah dinasti Ming melarang rakyatnya untuk ke luar dari Tiongkok, termasuk berdagang dan menetap di sana. Tahun 1727, kaisar Yongzheng (雍正) menyatakan bahwa semua pedagang Tionghoa yang berani melakukan pelayaran ke luar Tiongkok bukanlah kawula yang taat hukum (Kuhn, 2008:20) dan pernyataan ini diperkuat dengan dikeluarkannya dekrit kekaisaran pada tahun 1656. Ada pun yang dimaksud dengan kawula ialah rakyat dari suatu negara, dalam pengertian orang-orang yang berada di bawah perintah suatu negara (Poerwadarminta, 1976:453). Para pedagang Tionghoa yang mau berdagang di luar Tiongkok dihadapkan pada dua pilihan yaitu membatalkan niat mereka atau tetap menjalankan niat mereka tetapi dengan resiko dihukum apabila mereka berani kembali ke Tiongkok. Banyak pedagang yang memilih alternatif yang terakhir ini sehingga banyak di antara mereka yang kemudian tinggal di luar Tiongkok dan mengabdikan diri pada penguasa setempat atau menjadi perompak.

Kebijakan pemerintah dinasti Ming ini mengalami pasang surut hingga runtuhnya dinasti Qing (清朝, 1644-1912). Artinya dalam perjalanan waktu, adakalanya kebijakan ini tidak diberlakukan untuk kemudian diberlakukan kembali pada saat dianggap perlu. Berlaku tidaknya kebijakan ini bergantung pada perubahan situasi dan kondisi politik serta ekonomi di dalam maupun di luar kekaisaran Tiongkok. Namun terlepas dari semua itu, arus kepergian para pedagang Tionghoa ke luar Tiongkok yaitu ke wilayah "Laut Selatan" tetap berlangsung. Kebijakan ini justru mendorong para pedagang itu untuk tinggal lebih lama di daerah yang mereka tuju. Maka selama diberlakukannya kebijakan ini, kata qiao selalu dikaitkan dengan istilah liuyu (流寓) yang mengandung pengertian "berkelana dan pergi sementara". Artinya sampai sejauh ini, anggapan bahwa orang-orang Tionghoa yang ke luar Tiongkok itu adalah orang-orang yang pergi meninggalkan daerah asalnya dan tinggal lebih lama di tempat tujuan mereka karena 
terpaksa dan bahwa orang-orang ini adalah orang-orang yang tidak taat hukum, masih tetap berlaku. Adanya pemukiman orang-orang Tionghoa di luar Tiongkok pun belum mendapat pengakuan resmi. Tetapi perubahan ide yang terkandung dalam kata qiao ini ialah bahwa sejak diberlakukannya pelarangan terhadap kepergian orang-orang Tionghoa ke luar Tiongkok, kata ini jadi mengandung tiga macam pengertian. Pertama bahwa orang-orang Tionghoa yang pergi ini menjadi musafir dalam batas waktu yang tidak dapat ditentukan. Kedua, bahwa mereka menikah dengan perempuan setempat. Ketiga, bahwa keturunan mereka berasimilasi dengan masyarakat setempat. Ide ini paling tidak menunjukkan bahwa orang-orang Tionghoa yang pergi ke luar Tiongkok masih akan kembali ke daerah asalnya sekali pun mereka sudah berasimilasi dengan masyarakat di daerah yang mereka tuju.

Penjelajahan bangsa Barat ke bagian dunia lain sejak abad $13 \mathrm{M}$, termasuk ke wilayah Asia, juga berdampak pada perkembangan internal kekaisaran Tiongkok serta pada perkembangan hubungan perdagangan antara Tiongkok dengan wilayah "Laut Selatan". Pada paruh pertama abad 19 M, hasrat bangsa Barat untuk memperoleh hasil-hasil produksi kekaisaran Tiongkok yang dapat meningkatkan industri perdagangan mereka telah mendorong bangsa asing ini untuk mendesak kekaisaran Tiongkok membuka wilayahnya menjadi daerah-daerah konsesi bagi mereka melalui peperangan. Peperangan ini kemudian diakhiri dengan sejumlah perjanjian yang isinya menyebabkan Tiongkok jatuh menjadi negara semi-koloni dari bangsa-bangsa Barat. Situasi dan kondisi semacam ini yang disertai dengan terjadinya bencana alam serta adanya ketidakseimbangan antara laju pertambahan penduduk dengan peningkatan jumlah lahan subur di berbagai wilayah pedesaan di Tiongkok kian mendorong arus migrasi orang-orang Tionghoa ke luar dari Tiongkok. Di samping itu, situasi dan kondisi di wilayah "Laut Selatan" juga turut berperan dalam mendorong peningkatan arus migrasi orang-orang Tionghoa ke luar Tiongkok. Ekspansi bangsa Barat di kawasan ini telah mendorong bangsa-bangsa asing ini untuk melakukan investasi dalam jumlah besar di bidang perkebunan, pertambangan, serta pembangunan infrastruktur di wilayah Hindia-Belanda dan Malaya. Dampak dari tindakan ini ialah dibutuhkannya tenaga kuli dalam jumlah besar. Kesempatan ini dimanfaatkan oleh orang-orang Tionghoa, yang umumnya adalah petani, buruh tani, dan kaum miskin perkotaan untuk pergi meninggalkan Tiongkok dan bekerja sebagai tenaga kuli di wilayah "Laut Selatan". Mereka inilah yang kemudian dikenal dengan sebutan Huagong atau 华工 (Wang, 1991:6). Para kuli Tionghoa ini bekerja di wilayah "Laut Selatan" sampai kontrak kerja mereka berakhir dan setelah itu, banyak di antara mereka yang tinggal di sana dan mencari nafkah sebagai pedagang kecil, petani pasar atau tenaga terampil di berbagai bidang perdagangan (Govaars, 2005:17). Selain dikarenakan situasi dan kondisi di wilayah "Laut Selatan" yang kondusif, meningkatnya arus migrasi orang-orang Tionghoa ke wilayah "Laut Selatan" juga 
disebabkan oleh adanya pengiriman dana remitensi dari para pedagang dan kuli Tionghoa yang bekerja mencari nafkah di kawasan tersebut kepada keluarga dan sanak saudara mereka di daerah asal mereka di Tiongkok. Ada pun yang dimaksud dengan dana remitensi ialah pendapatan yang diperoleh orang-orang Tionghoa di luar Tiongkok dari hasil investasi serta hasil kerja mereka sebagai tenaga kuli, yang ditujukan untuk menghidupi keluarga dan anggota rumah-tangga mereka di negeri asal mereka pada kurun waktu tertentu (Hicks, 1993:252). Pengiriman dana semacam ini membuka mata banyak orang Tionghoa di Tiongkok mengenai dua hal. Pertama, bahwa ada tempat di luar Tiongkok di mana mereka berkesempatan untuk mencari keuntungan yang lebih. Kedua, bahwa dengan pergi ke luar Tiongkok, mereka pun punya kesempatan untuk bisa mengirim dana remitensi dari hasil pendapatan mereka, sama seperti sanak saudara mereka yang sudah mendahului tinggal di luar Tiongkok.

Dengan adanya perkembangan situasi dan kondisi kehidupan di dalam maupun di luar Tiongkok seperti yang dipaparkan di atas ini, maka terjadi pula perubahan persepsi yang signifikan terhadap orang-orang Tionghoa yang pergi ke luar Tiongkok. Pertama, muncul kesadaran akan adanya kawula kekaisaran Tiongkok yang menjadi penduduk sementara di wilayah di luar Tiongkok, yang membutuhkan perlindungan resmi dari kekaisaran Tiongkok. Kedua, adanya ijin bagi orang-orang Tionghoa yang pergi ke luar Tiongkok untuk membuat kontrak dengan orang asing dalam berbagai kegiatan yang kedua pihak lakukan. Ketiga, adanya pengakuan dari kekaisaran Tiongkok bahwa orangorang Tionghoa dari kelas menengah bawah diijinkan untuk bekerja mencari nafkah di luar wilayah Tiongkok, bahkan boleh membawa serta keluarganya. Keempat, terjadinya pergeseran status pada orang kebanyakan, yang disebabkan oleh diijinkannya pembelian gelar pejabat oleh para pedagang yang bukan hanya sukses tetapi juga patriotik, setia dan besar kontribusinya bagi kekaisaran Tiongkok (Wang, 1992:4-5). Perubahan yang paling signifikan ialah adanya penerimaan bahwa banyak di antara orang-orang Tionghoa yang tinggal di luar Tiongkok, yang bukan kawula asing dan juga bukan kawula kekaisaran Tiongkok yang bukan pengkhianat atau mata-mata. Dalam kenyataannya, banyak di antara mereka yang masih memegang teguh nilai-nilai budaya Tionghoa dan masih berkeinginan untuk kembali ke Tiongkok, selama mereka tidak dituduh sebagai pengkhianat. Perubahan pandangan mengenai orang-orang Tionghoa yang pergi ke luar Tiongkok ini tentunya juga berdampak pada makna kata qiao. Kata ini yang tadinya bermakna orang-orang Tionghoa yang merantau sementara ke luar Tiongkok dalam kurun waktu yang tidak pasti dan berasimilasi dengan masyarakat di daerah yang mereka tuju, kini memiliki makna baru. Makna baru yang dimaksud ialah bahwa kata qiao ini ditujukan pada orang-orang Tionghoa yang bukan kawula asing atau pun pengkhianat, yang bersama keluarga mereka pergi ke luar Tiongkok untuk mencari nafkah dalam kurun waktu tertentu dengan maksud akan kembali ke Tiongkok, dan yang oleh karenanya membutuhkan perlindungan resmi dari kekaisaran Tiongkok. 
Perlindungan secara resmi dari kekaisaran Tiongkok bagi orang-orang Tionghoa yang ke luar Tiongkok memang terasa menjadi suatu kebutuhan yang mendesak pada era 1880-an. Karena orang-orang Tionghoa ini seringkali mendapat perlakuan semenamena maupun diskriminatif dari para penguasa lokal di mana mereka tinggal dan mencari nafkah. Dalam rangka menyampaikan hal ini pada pemerintah dinasti Qing, seorang diplomat kekaisaran Tiongkok bernama Huang Zunxian membuat laporan tertulis yang resmi. Di dalam laporannya, Huang menggunakan istilah Huaqiao untuk menyebut orang-orang Tionghoa yang dimaksudkannya itu. Ini adalah untuk pertama kalinya istilah Huaqiao digunakan sebagai acuan terhadap orang-orang Tionghoa yang di luar Tiongkok (Wang, 1992:5). Pada dasarnya, isi laporan Huang ini menghimbau kekaisaran Tiongkok untuk mengklaim haknya atas orang-orang Tionghoa di luar Tiongkok tersebut sekaligus bertanggung jawab atas nasib mereka. Berarti kata qiao di sini mengandung konotasi adanya persetujuan dan perlindungan resmi dari kekaisaran Tiongkok bagi nasib orang-orang Tionghoa yang ke luar Tiongkok.

Konotasi yang sama juga terkandung dalam kata qiao yang digunakan dalam salah satu dokumen perjanjian antara Tiongkok dan Perancis yaitu Perjanjian Tianjin (1858). Ini adalah untuk pertama kalinya kata qiao digunakan secara resmi dalam sebuah dokumen kekaisaran. Tetapi dalam dokumen ini, kata qiao, yang dikaitkan dengan pengertian istilah qioaju (penduduk sementara), hanya ditujukan pada para pejabat yang ditempatkan di luar negaranya (yang dimaksudkan di sini ialah para pejabat kekaisaran Tiongkok maupun kerajaan Perancis yang ditempatkan di Paris maupun di Beijing). Barulah dalam Perjanjian Tongking (1885) antara Tiongkok dan Perancis, kata qiao yang dikaitkan dengan pengertian istilah qiaoju ini ditujukan pada orang-orang Tionghoa yang bukan pejabat yaitu "semua orang Tionghoa yang merupakan penduduk sementara maupun yang bukan penduduk tetap Tongking yang mengurusi usahanya dengan aman tenteram. Apakah mereka itu petani, pengrajin atau pedagang, keamanan dari harta benda mereka sama terjaminnya dengan keamanan dari harta benda milik penduduk yang di bawah perlindungan kerajaan Perancis, selama mereka tidak berbuat kesalahan apa pun" (Wang, 1992:6). Pada tahun 1896, kekaisaran Tiongkok menggunakan kata qiao dalam sebuah perjanjian dengan Jepang di bidang perdagangan dan perkapalan untuk menyatakan adanya jaminan perlindungan bagi hak-hak dari kawula kekaisaran Tiongkok yang tinggal di luar Tiongkok. Pada tahun 1898, Liang Qichao (梁启超) yang merupakan editor dari surat kabar harian Shiwu Bao di Shanghai memakai kata qiao untuk menyatakan para pedagang Tionghoa yang tinggal sementara (qiaoyu) di luar Tiongkok, yang membutuhkan perlindungan dari kekaisaran Tiongkok. Perkembangan politik di dalam maupun di luar wilayah kekaisaran Tiongkok di akhir abad $20 \mathrm{M}$ membuat kata qiao maupun istilah Huaqiao ini kembali mengalami perubahan makna.

Perubahan situasi dan kondisi politik di Tiongkok sebenarnya telah dimulai sejak paruh pertama abad $18 \mathrm{M}$ yaitu sejak kekaisaran Tiongkok dipaksa membuka wilayah 
kedaulatannya bagi bangsa-bangsa Barat melalui berbagai perjanjian yang sangat merugikan kepentingan Tiongkok. Melalui berbagai perjanjian ini, akhirnya kekaisaran Tiongkok jatuh menjadi daerah semi-koloni dari bangsa-bangsa Barat. Situasi dan kondisi kehidupan di kekaisaran Tiongkok semakin diperburuk oleh melemahnya wibawa dan menurunnya kekuasaan pemerintah dinasti Qing akibat korupsi, melemahnya sistem birokrasinya serta degradasi moral di kalangan militernya, yang menjadi salah satu tonggak penopang utama dari pemerintahan dinasti tersebut. Maka terjadilah pemberontakan dan gerakan perlawanan terhadap dinasti ini, baik di Tiongkok maupun di kalangan orangorang Tionghoa di luar Tiongkok. Salah satu di antaranya datang dari suatu kelompok yang ingin merubah Tiongkok dari kekaisaran menjadi republik yang demokratis melalui sebuah revolusi. Kelompok ini dikenal dengan sebutan kelompok revolusioner dan dipimpin oleh seorang dokter bernama Sun Yat-sen (Sun Zhongshan, 孙中山) asal propinsi Guangdong. Pendidikan yang diperolehnya di negara-negara Barat telah membuat tokoh ini berkenalan dengan ideologi maupun berbagai azas politik dan ekonomi yang berkembang di negara-negara Barat. Satu di antaranya ialah azas nasionalisme. Melalui azas ini, yang ia kemukakan dalam doktrinnya yang ternama yaitu San Min Zhuyi (三 民主义), Sun berusaha untuk menghidupkan rasa nasionalisme etnis Han (汉族), yang merupakan etnis mayoritas di Tiongkok, untuk menentang etnis Man (满族) yaitu etnis minoritas yang mendirikan dinasti Qing, yang dianggap Sun telah membawa Tiongkok menuju kehancuran. Pada Mei 1903, muncul istilah Huaqiao dalam sebuah syair berjudul Song of Revolution. Pada dasarnya, syair ini merupakan himbauan terhadap Huaqiao yaitu orang-orang Tionghoa di luar Tiongkok untuk tidak hanya menikmati hidup di tempat di mana mereka berada, tetapi untuk bangkit menentang etnis Man dan mendirikan sebuah republik Tiongkok bersama seluruh rakyat Tiongkok (Wang, 1992:7). Pada tahun 1906, Sun Yat-sen sendiri mulai memakai istilah Huaqiao untuk menyebut orang-orang Tionghoa di luar Tiongkok. Himbauan dan perjuangan Sun Yat-sen bersama kelompok revolusionernya ini telah membangkitkan rasa cinta akan negeri leluhur sekaligus menanamkan kesadaran akan identitas diri mereka sebagai bagian dari rakyat Tiongkok di kalangan orang-orang Tionghoa di luar Tiongkok. Sejak saat itu, timbul kesadaran di kalangan orang-orang Tionghoa ini bahwa mereka bukanlah pengkhianat dan juga bukan kawula asing. Mereka adalah orang Tionghoa yang tinggal di luar Tiongkok yang pada suatu saat akan kembali ke negeri leluhur mereka.

Melihat dukungan material maupun moril yang demikian besar dari orangorang Tionghoa di luar Tiongkok bagi perjuangan Sun Yat-sen serta kelompok revolusionernya, maka pemerintah dinasti Qing mulai menyadari bahwa orangorang Tionghoa ini memiliki potensi-potensi yang dibutuhkan dinasti ini untuk mempertahankan kekuasaannya. Untuk dapat memanfaatkan potensi yang dimiliki orang-orang Tionghoa di luar Tiongkok itu, pemerintah dinasti Qing menyadari bahwa mereka berkewajiban untuk memberikan perlindungan bagi orang-orang Tionghoa 
tersebut. Agar dapat memberikan perlindungan yang bersifat legal, maka pemerintah dinasti Qing menetapkan Regulasi Kekawulaan Dinasti Qing (Da Qing Guoji Tiaoli, 大 清国籍条例) pada tahun 1909. Isinya antara lain menyatakan bahwa semua orang Tionghoa di luar Tiongkok adalah kawula kekaisaran Tiongkok, apabila mereka kembali menetap di Tiongkok, sekali pun mereka sudah ditetapkan sebagai kawula dari wilayah di mana mereka menetap (Wang, 1992:8). Dengan adanya regulasi ini, berarti istilah Huaqiao ditujukan kepada semua orang Tionghoa di luar Tiongkok, tanpa membedakan mereka yang masih memegang nilai-nilai budaya Tionghoa, yang sudah berasimilasi dengan masyarakat setempat maupun mereka yang sudah diklaim oleh penguasa di mana mereka tinggal sebagai kawulanya. Bahkan orang-orang Tionghoa yang dituju di sini bukan hanya mencakup para pedagang dan kuli Tionghoa yang tinggal di luar Tiongkok, tetapi juga mencakup orang-orang Tionghoa di luar Tiongkok yang berprofesi sebagai wartawan dan tenaga-tenaga profesional, yang telah mempromosikan kesadaran mendalam akan budaya dan kepentingan Tiongkok di kalangan orangorang Tionghoa di luar Tiongkok (Wang, 1991:6-7). Maka istilah Huaqiao yang semula hanya dikaitkan dengan pengertian qiaoju dan qiaoyu, sejak diberlakukannya Regulasi Kekawulaan Dinasti Qing tahun 1909, memperoleh makna baru yang lebih luas yaitu makna yang membawa orang-orang Tionghoa pada kesadaran akan identitas mereka yang sebenarnya.

\section{ISTILAH HUAREN}

\section{ASAL-USUL DAN PERKEMBANGANNYA}

Istilah ini terdiri dari dua kata yaitu Hua (华) dan ren (人). Hua artinya Tiongkok sedangkan ren artinya orang. Jadi Huaren (华人) artinya orang Tionghoa., Istilah ini merupakan sebuah istilah yang punya konotasi budaya. Jika dikaitkan dengan orangorang Tionghoa di luar Tiongkok, pada tahap awal kemunculannya, istilah Huaren digunakan hanya untuk membedakan antara orang Tionghoa dan yang bukan Tionghoa. Hal ini terus berlangsung hingga usai Perang Dunia Kedua pada periode 1940-an di mana wilayah "Laut Selatan" (kini disebut Asia Tenggara) berkembang menjadi negaranegara merdeka yang berdaulat. Pada saat itu, pemerintahan di Tiongkok sudah beralih dari tangan kelompok nasionalis ke tangan kelompok komunis dan dikenal dengan Republik Rakyat Tiongkok (RRT，中华人民共和国). Paham komunis yang dianut oleh RRT ini telah menimbulkan keresahan di antara negara-negara di Asia Tenggara yang pada umumnya non-komunis. Timbul kekhawatiran di kalangan negara-negara ini bahwa pemerintah RRT akan menggunakan orang-orang Tionghoa di luar Tiongkok, tepatnya di Asia Tenggara, untuk menyebarluaskan paham komunis di wilayah di mana mereka menetap. Maka untuk menangkis anggapan ini, orang-orang Tionghoa di Asia Tenggara mulai meninggalkan istilah Huaqiao lalu mengadopsi istilah baru untuk mengidentifikasi diri mereka sendiri yaitu Huaren. Mengapa orang-orang Tionghoa ini bersikap demikian 
ialah karena istilah Huaqiao mengandung konotasi bahwa mereka adalah orang-orang Tionghoa yang hanya tinggal sementara di luar Tiongkok yang pada suatu hari nanti akan kembali ke Tiongkok. Faktor inilah yang ingin dibuktikan ketidakbenarannya oleh orangorang Tionghoa di Asia Tenggara. Mereka justru ingin menunjukkan bahwa mereka sudah memilih untuk menetap di Asia Tenggara, bahkan banyak di antara mereka yang kemudian memilih menjadi warganegara dari negara di mana mereka tinggal. Mereka yang mula-mula memakai istilah Huaren untuk mengidentifikasi diri ialah orang-orang Tionghoa yang masih fasih berbahasa Tionghoa di Malaya dan Singapura (Suryadinata, 1997:2). Kemudian istilah ini berkembang menjadi istilah yang mengacu pada semua orang Tionghoa di Asia Tenggara yang sudah menjadi warganegara dari negara di mana mereka menetap. Akhirnya, istilah Huaren digunakan oleh orang-orang Tionghoa di Asia Tenggara untuk mengidentifikasi semua orang Tionghoa yang menetap di Asia Tenggara, baik yang sudah warganegara dari negara di mana ia menetap maupun yang masih warganegara RRT tetapi menetap di Asia Tenggara.

Bagi pemerintah RRT, sampai dengan periode 1970-an, semua orang Tionghoa di luar Tiongkok disebut Huaqiao. Karena pemerintah RRT beranggapan bahwa semua orang Tionghoa di luar Tiongkok merupakan bagian integral dari bangsa Tionghoa, yang oleh karenanya, suatu saat akan kembali ke Tiongkok untuk menetap di sana. Anggapan ini diwujudkan secara nyata dalam bentuk undang-undang kewarganegaraan dan terus berlaku hingga naiknya seorang tokoh komunis yang pragmatis ke tampuk pimpinan RRT yaitu Deng Xiaoping (邓小平). Salah satu butir dari hasil pertemuan Deng dengan delegasi orang-orang Tionghoa di luar Tiongkok di akhir tahun 1977 ialah bahwa sekali pun pemerintah RRT telah menganjurkan orang-orang Tionghoa di luar Tiongkok untuk menjadi warganegara dari negara di mana mereka menetap selama ini, atas kemauan sendiri atau melalui naturalisasi, namun orang-orang Tionghoa tersebut tetap dianggap sebagai 'famili (kinfolk) dan teman' dari bangsa Tionghoa. Hasil pertemuan ini dimuat dalam editorial surat kabar Renmin Ribao (人民日报, Harian Rakyat) edisi 4 Januari 1978 (Suryadinata, 1985:70). Tanpa Deng sadari, putusan yang diambilnya ini kembali membangkitkan kecurigaan negara-negara Asia Tenggara terhadap RRT berkaitan dengan masalah orang-orang Tionghoa di Asia Tenggara. Kecurigaan itu baru terdeteksi oleh pemerintah RRT, ketika Deng mengadakan kunjungan ke negara-negara Asia Tenggara pada tahun 1978 untuk menjalin kembali hubungan baik dengan negaranegara tersebut. Ada dua kepentingan yang bersifat timbal-balik, yang melatarbelakangi pemerintah RRT untuk kembali membina hubungan baik dengan negara-negara Asia Tenggara tersebut. Pertama ialah faktor pentingnya potensi yang dimiliki orang-orang Tionghoa di Asia Tenggara bagi kepentingan pembangunan dalam negeri RRT. Kedua ialah faktor besarnya jumlah orang Tionghoa yang menetap di kawasan itu. Populasi orang Tionghoa yang besar jumlahnya itu tentunya merupakan lahan keuntungan yang subur bagi kepentingan dalam negeri RRT. Karena dengan semakin besarnya jumlah 
orang Tionghoa yang berpotensi, makin besar pula keuntungan yang dapat diperoleh RRT. Namun pemerintah RRT juga menyadari bahwa keuntungan yang besar itu hanya dapat diperolehnya, apabila ia menjalin hubungan baik dengan negara-negara di mana orang-orang Tionghoa di luar Tiongkok itu menetap. Karena dengan demikian, RRT bukan hanya dapat memperoleh keuntungan yang besar, tetapi sekaligus juga dapat menjaga keamanan wilayahnya maupun keamanan serta kepentingan orang-orang Tionghoa di Asia Tenggara itu sendiri, sebagai bagian dari bangsa Tionghoa. Selain itu, melalui kunjungan yang dilakukannya ini, Deng baru menyadari bahwa cukup besar jumlah orang Tionghoa di Asia Tenggara yang mengidentifikasi dirinya sebagai bagian dari bangsa di mana mereka menetap, dan bukan lagi sebagai Huaqiao. Berarti cukup banyak orang Tionghoa di Asia Tenggara yang tidak lagi menganggap diri mereka sebagai bagian dari bangsa Tionghoa, seperti yang diharapkan pemerintah RRT selama ini. Maka sekembalinya Deng ke RRT, ada pemisahan yang jelas dalam penggunaan istilah untuk menyebut orang-orang Tionghoa di luar RRT dalam semua dokumen resmi pemerintah RRT. Untuk menyebut semua orang Tionghoa yang menetap di luar RRT dan sudah menjadi warganegara dari negara di mana ia menetap, digunakan istilah Huaren. Untuk menyebut semua orang Tionghoa, pemegang paspor RRT, yang merantau di negara lain, digunakan istilah Huaqiao (Zhou, 1998:355).

Dengan demikian berarti istilah Huaren mempunyai perbedaan makna di mata pemerintah RRT dan di mata orang-orang Tionghoa yang menetap di luar Tiongkok yaitu di Asia Tenggara. Bagi pemerintah Tiongkok, istilah Huaren mengandung konotasi politik karena dikaitkan dengan kewarganegaraan orang Tionghoa di luar Tiongkok. Tetapi bagi orang Tionghoa di Asia Tenggara, istilah Huaren hanya menunjukkan bahwa mereka adalah orang yang berlatarbelakang budaya Tionghoa, lepas dari batasan-batasan politik. Oleh karena itu, istilah Huaren ini lebih populer digunakan di kalangan orang-orang Tionghoa di Asia Tenggara karena makna budaya yang terkandung di dalamnya.

\section{PENUTUP}

Muncul dan berkembangnya istilah Huaqiao dan Huaren merupakan sebuah proses yang panjang. Apa yang unik dari proses ini ialah bahwa muncul dan berkembangnya kedua istilah itu tidak dapat hanya ditinjau dari segi etimologi saja, tetapi justru segi historis-lah yang memberi warna dan makna yang signifikan bagi kedua istilah tersebut. Ada dua faktor historis yang sangat mempengaruhi kemunculan dan perkembangan makna dari kedua istilah ini. Faktor pertama ialah migrasi. Tanpa terjadinya migrasi orang-orang Tionghoa ke luar Tiongkok, tentunya kedua istilah ini tidak akan eksis. Tetapi faktor migrasi ini pun tidak dapat hanya ditinjau dari segi migrasinya semata. Untuk dapat memahami mengapa dan bagaimana sampai kedua istilah ini muncul serta mengalami perkembangan dan perubahan makna, harus dikaitkan pula dengan bagaimana persepsi maupun sikap pemerintah Tiongkok terhadap kawulanya yang 
migrasi ke luar dari negara mereka. Faktor ini erat kaitannya dengan faktor kedua yaitu faktor politik, yang sangat besar pengaruhnya terhadap proses kemunculan dan perkembangan dari istilah Huaqiao dan Huaren. Kedua istilah ini tidak akan mencapai makna yang dimilikinya saat ini, jika tidak dipengaruhi oleh perubahan dan perkembangan situasi dan kondisi politik di dalam maupun di luar Tiongkok. Situasi dan kondisi inilah yang kemudian merubah persepsi pemerintah Tiongkok mengenai migrasi orang-orang Tionghoa ke luar Tiongkok, yang selanjutnya mempengaruhi perkembangan makna dari istilah Huaqiao dan Huaren.

Apakah kedua istilah ini akan selalu eksis? Jika ya, bagaimana perkembangan selanjutnya?. Apakah keduanya akan kembali mengalami perubahan makna? Tidak ada yang tahu. Karena seiring dengan berkembangnya jaman, akan muncul berbagai persepsi, situasi dan kondisi baru yang mungkin akan memberi nuansa baru pada kedua istilah tersebut atau justru akan melahirkan istilah Huaqiao dan Huaren yang baru.

\section{DAFTAR PUSTAKA}

Cai, Renlong. Yindunixiya Huaqiao Shi (Sejarah Orang Tionghoa di Luar Tiongkok di Indonesia). Beijing: Haiyang Chubanshe. 1985.

Fitzgerald, C.P. The Southern Expansion Of The Chinese People. New York: Praeger Publishers, Inc. 1972.

Govaars, Ming. Dutch Colonial Education:The Chinese Experience in Indonesia, 19001942. Singapore: Chinese Heritage Centre. 2005.

Heidhues, Mary F.Somers. Southeast Asia's Chinese Minorities. Hawthorn: Longman Australia Pty Limited. 1974.

Hicks, George L., ed. Overseas Chinese Remittances From Southeast Asia 1910-1940. Singapore: Select Book Pte Ltd. 1993.

Hooker, M.Barry, ed. Law and The Chinese in Southeast Asia. Singapore: Institute of Southeast Asian Studies. 2002.

Kuhn, Philip A. Chinese Among Others:Emigration in Modern Times. Singapore: NUS Press. 2008.

Lee, Lai To, ed. The 1911 Revolution-The Chinese in British and Dutch Southeast Asia. Singapore: Heinemann Publishers Asia Pte Ltd. 1987.

Li, Xuemin, et.al. Yinni Huaqiao Shi: Gudai zhi 1949 Nian (Sejarah Orang Tionghoa di Indonesia: Dari Jaman Kuno Hingga Tahun 1949). Guangzhou: Guangdong Deng Jiaoyu Chubanshe. 2005.

Ma, J.C.Laurence \& Carolyn Cartier (ed.). The Chinese Diaspora: Space, Place, Mobility, and Identity. Lanham: Rowman \& Littlefield Publishers, Inc. 2003.

Mao, Qixiong, et.al. Zhongguo Qiaowu Zhengce Gaishu (Garis Besar Kebijakan Pemerintah Tiongkok Mengenai Masalah Orang Tionghoa di Luar Tiongkok). Beijing: Zhongguo Huaqiao Chubanshe. 1993. 
Pan, Ling. Haiwai Huaren Baiquan Keshu (Ensiklopedia Mengenai Orang Tionghoa di Luar Tiongkok). Hong Kong: Sanlian Shudian Youxian Gongsi. 1998.

Poerwadarminta, W.J.S. Kamus Umum Bahasa Indonesia. Jakarta: PN Balai Pustaka. 1976.

Seda, Joanessa M.J.S. "Perkembangan Kebijakan Pemerintah Cina Mengenai Dwikewarganegaraan Etnis Cina Di Asia Tenggara (1909-2000)". Tesis yang diajukan untuk melengkapi persyaratan perolehan gelar Magister Humaniora pada Program Pascasarjana Ilmu Sejarah, Fakultas Ilmu Pengetahuan Budaya, Universitas Indonesia, Depok. 2007.

Stuart-Fox, Martin. A Short History Of China And Southeast Asia:Tribute, Trade And Influence. New South Wales: Allen \& Unwin. 2003.

Suryadinata, Leo, ed. Ethnic Chinese as Southeast Asians. Singapore: Institute of Southeast Asian Studies. 1997.

- Peranakan Chinese In A Globalizing Southeast Asia. Singapore: Chinese Heritage Centre \& Baba House. 2010.

Wang, Gungwu. China and The Chinese Overseas. Singapore: Times Academic Press. 1991. . Community and Nation:China, Southeast Asia and Australia. New South Wales: Allen \& Unwin Pty Ltd. 1992. . Don't Leave Home: Migration and The Chinese. Singapore: Times Media Private Limited. 2003.

Zhongguo Da Baike Quanshu Zhongbian Weiyuanhui. Zhongguo Da Baike Quanshu:Faxue (Ensiklopedia Hukum Tiongkok). Beijing: Zhongguo Da Baike Quanshu Chubanshe. 1984.

Zhou, Nanjing, ed. Huaqiao Huaren Yanjiu Lun Cong (Kumpulan Penelitian Mengenai Orang Tionghoa di Luar Tiongkok). Beijing: Zhongguo Huaqiao Chubanshe. 1998. 